\title{
BUDIDAYA TERPADU IKAN BANDENG, Chanos chanos DAN AYAM BURAS DENGAN TIPE KANDANG BERBEDA
}

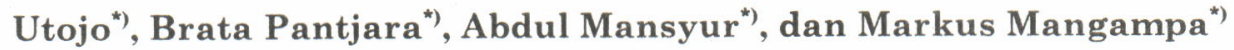

\begin{abstract}
ABSTRAK
Penelitian ini bertujuan untuk mengetahui pengaruh tipe kandang ayam yang berbeda terhadap pertumbuhan bobot, sintasan, dan produksi ikan bandeng di tambak. Penelitian berlangsung selama 75 hari dengan menggunakan 9 petakan tambak masing-masing berukuran $1.000 \mathrm{~m}^{2}$ dengan kedalaman air 70-80 cm. Bobot awal ikan bandeng 6,03 g/ekor dengan padat penebaran 300 ekor/petak (3.000 ekor/ha). Bobot awal ayam 550 g/ekor dengan jumlah 25 ekor/ kandang. Kandang ayam berukuran $5 \times 2 \times 1,75 \mathrm{~m}^{3}$. Rancangan yang digunakan dalam penelitian ini adalah rancangan acak lengkap dengan perlakuan kandang ayam tancap dan terapung, yaitu bandeng + kandang ayam tancap, bandeng + kandang ayam terapung, dan kontrol (tanpa kandang ayam), masing-masing dengan tiga kali ulangan. Hasil penelitian menunjukkan bahwa pertumbuhan bobot dan produksi bandeng pada perlakuan bandeng + kandang ayam terapung lebih baik $(\mathrm{P}<0,05)$ dibanding dengan perlakuan bandeng + kandang ayam tancap dan kontrol. Sintasan pada perlakuan bandeng + kandang ayam tancap dan bandeng + kandang ayam terapung tidak berbeda nyata $(\mathrm{P}>0,05)$, tetapi lebih tinggi dari pada kontrol.
\end{abstract}

ABSTRACT: Integrated farming of milkfish, Chanos chanos and chicken using different coop types. By: Utojo, Brata Pantjara, Abdul Mansyur, and Markus Mangampa.

The objective of the research was to study the effect of chicken coop types in the integrated farming system on the growth, survival rate, and production of milkfish in pond. The research was carried out for 75 days in 9 ponds of $1.000 \mathrm{~m}^{2}$ each with water depth of $70-80 \mathrm{~cm}$. Initial average weight of milkfish was $6.03 \mathrm{~g}$ with stocking density of 300 individuals / pond. Size of chicken coop was $5 \times 2 \times 1.75 \mathrm{~m}^{3}$ stocked with 25 individuals. The experiment used completely randomized design with two treatments i.e. pen and floating coops (milkfish + pen coop and milkfish + floating coop) and control (without coop), each with three replications. The results showed that growth in weight and production of milkfish of milkfish + floating coop treatment were higher $(P<0.05)$ than treatments of milkfish + pen coop and control. The survival rates of milkfish treatments of milkfish + pen coop and milkfish + floating coop were not significantly different $(P>0.05)$, but significantly higher $(P<0.05)$ than control.

KEYWORDS: Integrated farming system, milkfish, chicken, fish ponds.

\section{PENDAHULUAN}

Satu di antara sejumlah cara yang mungkin ditempuh untuk mengoptimalkan produktivitas lahan perairan yang semakin terbatas adalah dengan mengefisiensikan penggunaannya melalui usaha budidaya terpadu (Sin, 1980).

Belakangan ini budidaya terpadu bukan hanya berupa pemeliharaan ikan bersama padi, tetapi telah banyak modifikasi yang dilakukan, khususnya di Asia Tenggara (Chen dalam Koesoemadinata, 1980). Usaha budidaya terpadu memberikan banyak keuntungan antara lain peningkatan efisiensi penggunaan areal tanah dan perairan, reduksi dalam biaya produksi, peningkatan kapasitas berproduksi yang secara langsung akan meningkatkan pendapatan dan kesejahteraan petani (Sin, 1980).

Permasalahan lingkungan yang tidak sehat seperti bau busuk dan kerumunan lalat yang timbul dari kotoran hewan ternak di darat dapat pula dipecahkan melalui budidaya terpadu dengan perikanan (Stickney, 1979). Motivasi dari budidaya terpadu lebih mendayagunakan lahan

*) Peneliti pada Balai Penelitian Perikanan Pantai 
yang tersedia. Keterpaduan ikan bandeng dan ayam buras dalam pemanfaatan relung ekologis, terutama perolehan ruang dan pakan, diharapkan lebih efisien dan efektif, sedangkan kotorannya mengendap di dasar tambak merupakan bahan organik yang mengandung nitrogen dalam bentuk persenyawaan tingkat tinggi seperti dalam bentuk protein. Oleh bakteri pembusuk, protein diuraikan dan dihasilkan asam amino yang selanjutnya dapat merangsang pertumbuhan pakan alami (Mintardjo et al., 1984; Cholik \& Yakob, 1987).

Menurut Tang (1979), kandungan unsur-unsur yang terdapat pada kotoran ayam yaitu $1 \% \mathrm{~N}$, $0,8 \% \mathrm{P}_{2} \mathrm{O}_{5}$ dan $0,4 \% \mathrm{~K}_{2}$. Selanjutnya dikatakan bahwa bila bahan organik membusuk, zat nitrogen yang terdapat di dalamnya akan larut sehingga dapat dimanfaatkan oleh alga untuk pertumbuhannya

Tingkat kesuburan perairan tambak dalam sistem usaha budidaya terpadu ini berasal dari kontribusi dan distribusi unsur hara hasil pasokan bahan organik yang sangat bergantung pada banyaknya kotoran, sisa pakan, dan jumlah ayam per kandang serta daya dukung lahan. Pada umumnya budidaya terpadu ikan dan ayam dilakukan di kolam dengan menggunakan tipe kandang ayam tancap (Kusno, 1991), tetapi belum didapatkan informasi mengenai peranan bahan organik dari kotoran ayam sebagai penyedia pakan alami bagi ikan dengan menggunakan tipe kandang ayam terapung. Dalam budidaya terpadu ikan bandeng dan ayam buras dengan tipe kandang terapung diharapkan kontribusi dan distribusi unsur hara dari kotoran ayam sebagai penyedia pakan alami lebih merata ke seluruh areal dasar tambak tanpa menurunkan kualitas airnya sehingga dapat meningkatkan produksi ikan bandeng.

\section{BAHAN DAN METODE}

Penelitian dilaksanakan di Instalasi Tambak Percobaan Balai Penelitian Perikanan Pantai Maranak, Maros selama 75 hari mulai tanggal 14 Desember 1995 sampai 27 Februari 1996, dengan menggunakan tambak berukuran 0,1 ha sebanyak 9 petak. Dalam tahap persiapan dilakukan perbaikan pematang, pintu air, perataan dan pengeringan pelataran tambak sampai retakretak. Kemudian air dimasukkan ke dalam tambak sampai macak-macak dan dilakukan pemberantasan hama menggunakan saponin dengan dosis $30 \mathrm{ppm}$. Setelah pencucian kemudian dikeringkan kembali dan tanah dasar semua tambak (termasuk kontrol) diberi kapur secara merata dengan menggunakan kapur pertanian $\left(\mathrm{C}_{\mathrm{a}} \mathrm{CO}_{3}\right)$ sebanyak 2 ton/ha. Kemudian air dimasukkan ke dalam tambak sampai macakmacak dan dilakukan pemupukan dengan menggunakan kotoran ayam kering sebanyak 1 ton/ha, urea $150 \mathrm{~kg} / \mathrm{ha}$, dan TSP $75 \mathrm{~kg} / \mathrm{ha}$. Penumbuhan pakan alami dilakukan dengan metode air dangkal (Ilyas et al., 1987). Setelah pakan alami tumbuh, air dinaikkan setinggi $80 \mathrm{~cm}$ dan dipertahankan sampai penelitian berakhir. Selama penelitian, dilakukan pergantian air sebanyak $30-50 \%$ dari volume tambak pada setiap periode pasang tinggi.

Hewan uji yang digunakan berupa gelondongan bandeng dengan bobot 6,03 g/ekor dan padat penebaran 3.000 ekor/ha. Penebaran bandeng dilakukan seminggu setelah ayam dikandangkan di atas tambak, yaitu pada saat pakan alami mulai tumbuh dengan baik. Ayam buras dengan bobot 550 g/ekor dipelihara dengan jumlah 25 ekor/kandang. Kandang ayam berukuran 5 x 2 x $1,75 \mathrm{~m}^{3}$. Dalam penelitian ayam diberikan pakan komersial (comfeed) dengan perhitungan setiap ekor mengkonsumsi pakan $80 \mathrm{~g} / \mathrm{hari}$ dan air minum $250 \mathrm{~mL} / \mathrm{hari}$.

Dalam penelitian ini digunakan rancangan acak lengkap (RAL) dengan perlakuan perbedaan tipe kandang ayam yaitu A (bandeng + kandang ayam tancap), B (bandeng + kandang ayam terapung), dan $\mathrm{C}$ (kontrol), masing-masing dengan tiga kali ulangan. Perlakuan kandang ayam tancap ditempatkan dekat pintu air dengan tinggi $1 \mathrm{~m}$ di atas permukaan air. Kandang ayam terapung masing-masing dengan enam pelampung yang digerakkan ke seluruh areal tambak dengan interval waktu tiga kali seminggu. Penimbangan bobot.bandeng dilakukan pada awal dan akhir penelitian dengan menggunakan "Triple Beam Balance" kapasitas $2.610 \mathrm{~g}$ dengan ketelitian 0,1 g. Sintasan bandeng dihitung pada akhir penelitian (Effendie, 1979). Produksi bandeng dihitung berdasarkan penimbangan bobot biomassa individu yang dipanen.

Untuk mengetahui kelayakan habitat bagi kehidupan dan pertumbuhan bandeng, dilakukan pengamatan terhadap beberapa peubah kualitas air setiap tujuh hari meliputi suhu dan oksigen 
terlarut dengan DO meter YSI $58, \mathrm{pH}$ dengan $\mathrm{pH}$ meter VWV 252, salinitas dengan Handy Refractometer, bahan organik total, suspensi total yang terlarut, $\mathrm{NH}_{3}-\mathrm{N}, \mathrm{NO}_{2}-\mathrm{N}, \mathrm{NO}_{3}-\mathrm{N}, \mathrm{PO}_{4}-\mathrm{P}$, dan $\mathrm{Fe}$ dengan spektrofotometer 21. Pengamatan peubah kualitas tanah dilakukan pada awal dan akhir penelitian meliputi $\mathrm{pH}$, bahan organik total dan tekstur tanah. Pengamatan pakan alami (plankton) secara mikroskopis dilakukan setiap 14 hari dengan mengidentifikasi jenisnya (sampai tingkat genera) yang berpedoman pada Sachlan (1980), Yamaji (1966), Newell dan Newell (1977), dan Hadijjah (1985), sedangkan jumlah plankton dihitung berdasarkan rumus Lackey Drop Micro Transect Counting Method yang dimodifikasi oleh Anggoro (1984).

Analisis data dilakukan dengan bantuan paket program statistik MSUSTAT (Lund, 1985) yang digunakan untuk mengetahui pengaruh perlakuan terhadap pertumbuhan bobot, sintasan dan produksi bandeng. Peubah yang berbeda nyata diuji lanjut dengan uji Beda Nyata Terkecil (BNT) pada selang kepercayaan 95\% (Petersen, 1985). Sedangkan data kelayakan habitat (kualitas tanah dan air) untuk kehidupan dan pertumbuhan bandeng dianalisis secara deskriptif.

\section{HASIL DAN PEMBAHASAN}

\section{Pertumbuhan}

Hasil penelitian selama 75 hari menunjukkan bahwa pertumbuhan bobot ikan bandeng dipe- ngaruhi secara nyata $(\mathrm{P}<0,05)$ oleh tipe kandang ayam buras yang dicobakan (Tabel 1).

Pertumbuhan bobot ikan bandeng yang tertinggi dicapai pada perlakuan tipe kandang ayam terapung (131,8 g/ekor), kemudian disusul perlakuan tipe kandang ayam tancap (114,2 g/ekor), dan yang terendah pada kontrol (63,5 g/ekor). Hal ini disebabkan karena kandang ayam terapung mempunyai kontinuitas kontribusi dan distribusi unsur hara terutama $\mathrm{N}$ dan $\mathrm{P}$ yang lebih merata bagi pakan alami daripada perlakuan lain.

Komposisi dan jumlah plankton pada masingmasing perlakuan selama penelitian bervariasi (Tabel 2).

Komposisi dan jumlah plankton yang tertinggi dicapai pada perlakuan tipe kandang ayam terapung (Navicula spp., Acartia spp., Nitzschia spp., Pleurosigma spp., Oscillatoria spp., Amphora spp., Biddulphia spp., Rhizosolenia spp., Coscinodiscus spp., Gyrosigma spp., Phormidium spp., dan Brachi-onus spp.) sebanyak $408 \mathrm{sel} / \mathrm{mL}$, kemudian disusul perlakuan tipe kandang ayam tancap (Navicula spp., Acartia spp., Nitzschia spp., Pleurosigina spp., Oscillatoria spp., Kellicotia spp., Amphora spp., Biddulphia spp., dan Ceratium spp.) sebanyak $200 \mathrm{sel} / \mathrm{mL}$ dan kontrol (Navicula spp., Acartia spp., Coscinodiscus spp., Oscillatoria spp., Amphora spp., dan Biddulphia spp.) sebanyak $92 \mathrm{sel} / \mathrm{mL}$. Hal ini diduga bahwa semakin banyak keragaman spesies dan jumlah plankton pada setiap perlakuan, semakin tinggi

Tabel 1. Pertumbuhan bobot, sintasan, dan produksi ikan bandeng, Chanos chanos di tambak dengan tipe kandang ayam berbeda selama 75 hari.

Table 1. Weight gain, survival rate, and production of milkfish, Chanos chanos in the pond with different types of chicken coop during 75 days.

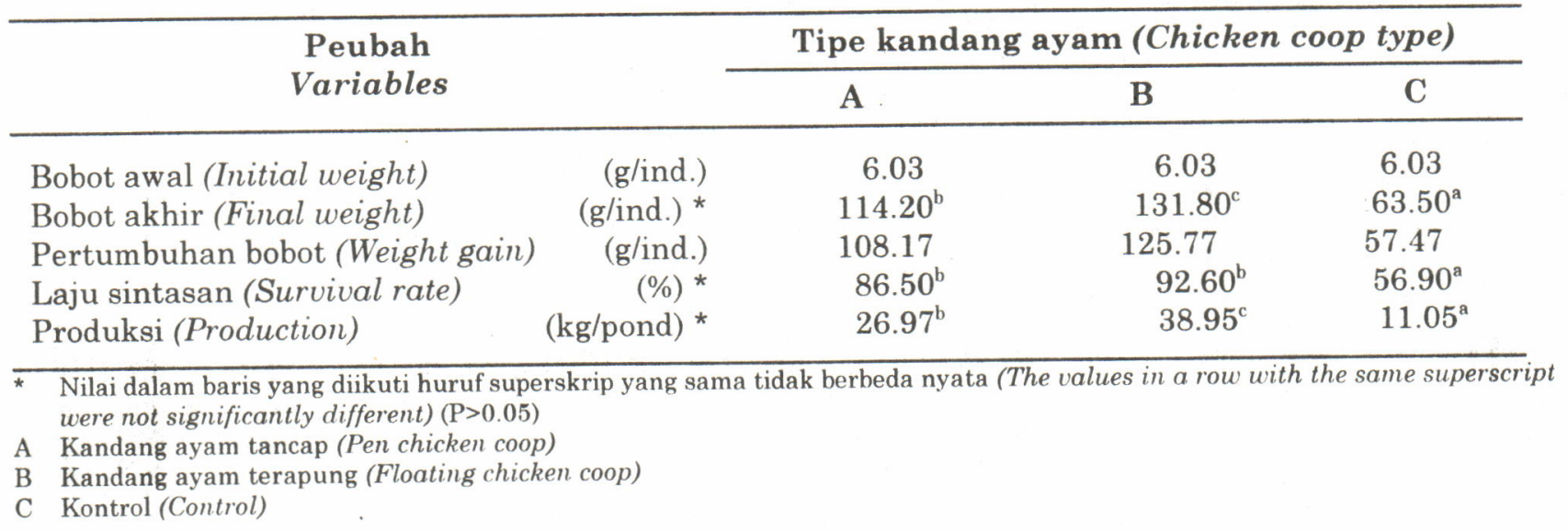


Tabel 2. Komposisi dan jumlah plankton (sel/mL) pada budidaya terpadu ikan bandeng, Chanos chanos dan ayam buras di tambak dengan tipe kandang ayam berbeda selama 75 hari.

Table 2. Composition and abundance of plankton (cell/mL) at integrated farming of milkfish, Chanos chanos and chicken in the ponds with different chicken coop types during 75 days.

\begin{tabular}{|c|c|c|c|c|c|c|c|c|c|c|c|c|c|c|c|}
\hline \multirow{3}{*}{$\begin{array}{l}\text { Komposisi spesies } \\
\text { Species Composition }\end{array}$} & \multicolumn{15}{|c|}{ Interval } \\
\hline & \multicolumn{3}{|c|}{$\begin{array}{c}\text { 2-minggu } \\
\text { 2-week }\end{array}$} & \multicolumn{3}{|c|}{$\begin{array}{c}\text { 4-minggu } \\
\text { 4-week }\end{array}$} & \multicolumn{3}{|c|}{$\begin{array}{c}\text { 6-minggu } \\
\text { 6-week }\end{array}$} & \multicolumn{3}{|c|}{$\begin{array}{c}\text { 8-minggu } \\
\text { 8-week }\end{array}$} & \multicolumn{3}{|c|}{$\begin{array}{c}\text { 10-minggu } \\
10 \text {-week }\end{array}$} \\
\hline & A & B & $\mathrm{C}$ & A & B & C & $\mathbf{A}$ & $\mathbf{B}$ & $\mathbf{C}$ & $\mathbf{A}$ & B & $\mathbf{C}$ & $\mathbf{A}$ & B & $\mathrm{C}$ \\
\hline Navicula spp. & 20 & 30 & 20 & 30 & 50 & 10 & 20 & 40 & 10 & 40 & 30 & 20 & 30 & 80 & 20 \\
\hline Acartia spp. & 60 & 110 & 30 & 50 & 40 & 10 & 30 & 30 & 10 & 20 & 40 & 10 & 20 & 10 & 10 \\
\hline Nitzschia spp. & 30 & 20 & 10 & - & 30 & 10 & $\cdot$ & 30 & - & $\cdot$ & 20 & $\cdot$ & 60 & 40 & - \\
\hline Pleurosigma spp. & 50 & 50 & - & 40 & 150 & 30 & 40 & 80 & 20 & 30 & 70 & - & 20 & 180 & - \\
\hline Coscinodiscus spp. & 20 & 20 & 10 & - & - & - & 20 & $\dot{r}$ & 10 & $\cdot$ & - & 10 & $\cdot$ & 30 & 20 \\
\hline Gyrosigma spp. & - & 30 & - & - & - & - & - & 70 & - & 30 & 50 & - & - & 50 & - \\
\hline Oscillatoria spp. & - & - & - & 10 & 40 & 30 & 10 & 10 & 20 & 20 & 10 & 10 & 20 & 20 & 10 \\
\hline Kellicotia spp. & - & - & - & 10 & - & 10 & - & - & - & $\cdot$ & - & $\cdot$ & 10 & - & - \\
\hline Amphora spp. & - & - & 10 & 60 & 70 & 20 & 10 & 40 & 10 & 10 & 30 & 10 & 30 & 60 & 20 \\
\hline Biddulphia spp. & - & - & - & - & $\cdot$ & - & - & $\cdot$ & $\cdot$ & 10 & $\cdot$ & $\cdot$ & 10 & 30 & 10 \\
\hline Rhizosolenia spp. & - & $\cdot$ & - & - & - & - & - & - & $\cdot$ & - & - & - & $\cdot$ & 20 & - \\
\hline Cymbella spp. & - & 40 & - & - & 30 & - & - & 20 & - & 10 & 30 & - & - & - & - \\
\hline Phormidium spp. & $\cdot$ & $\cdot$ & - & - & - & - & - & $\cdot$ & - & - & 10 & - & - & 20 & - \\
\hline Ceratium spp. & - & - & - & $\cdot$ & $\cdot$ & - & - & - & $\cdot$ & $\cdot$ & - & - & 10 & $\cdot$ & - \\
\hline Brachionus spp. & 50 & 60 & 30 & 40 & 50 & - & 10 & 20 & - & 10 & 20 & - & - & 30 & - \\
\hline
\end{tabular}

A Kandang ayam tancap (Pen chicken coop)

B Kandang ayam terapung (Floating chicken coop)

C Kontrol (Control)

tinggi tingkat kesuburan perairan tambak dalam peranannya sebagai sumber pakan alami bandeng. Menurut Bambang dan Pirzan (1977), hasil analisis lambung ikan bandeng didapatkan spesies plankton antara lain Nodularia spp. (21,8\%), Spirulina spp. (21,02\%), Lyngbya spp. (19,04\%), Pleurosigma spp. (13,5\%), Rhizosolenia spp. (5,47\%), Oscillatoria spp. (3,96\%), dan mikroorganisme lainnya yang tidak terdeteksi $(15,26 \%)$. Pertumbuhan dan sintasan ikan bandeng, sangat ditentukan oleh nilai cerna dan kandungan nutrisi plankton, serta daya serap bandeng terhadap plankton. Menurut Cholik (1979) kandungan protein yang dapat dicerna dari plankton adalah $80 \%$ bobot basah. Selanjutnya nilai nutrisi plankton segar makanan bandeng antara lain lemak kasar 1,3\%, protein kasar 3,5\%, ekstrak $\mathrm{N}$ bebas $6,1 \%$, serat kasar $0,4 \%$, dan mineral $0,7 \%$. Selanjutnya menurut Huet (1971) daya serap ikan ditentukan oleh kemampuannya dalam memanfaatkan pakan.

Bahan organik total tanah pada tipe kandang ayam tancap berkisar $10,26-22,33 \%$, pada tipe kandang ayam terapung $8,53-10,20 \%$, dan kontrol $8,18-8,38 \%$ (Tabel 3). Diduga bahwa semakin tinggi kandungan bahan organik dalam tambak pada setiap perlakuan, menyebabkan semakin meningkat kadar amonia $\left(\mathrm{NH}_{3}-\mathrm{N}\right)$ dan nitrit $\left(\mathrm{NO}_{2}-\mathrm{N}\right)$ hasil nitrifikasi. Menurut Soepardi (1983) kandungan bahan organik tanah yang berlebihan dalam kondisi alkalis dan lingkungan aerobik dapat menghambat kerja bakteri Nitrobacter dalam proses nitrifikasi sehingga terjadi penimbunan kandungan nitrit sebagai produk antara proses nitrifikasi yang dapat menghambat pertumbuhan pakan alami. Sedangkan bahan organik tanah setelah diuraikan oleh bakteri, menjadi ion-ion nitrat dan $\mathrm{NH}_{4}^{+}$, dapat langsung dimanfaatkan untuk pertumbuhan pakan alami (Mintardjo et al., 1984).

\section{Sintasan}

Sintasan ikan bandeng di tambak kontrol $(56,9 \%)$ lebih rendah daripada tipe kandang ayam terapung $(92,6 \%)$ dan tancap $(86,5 \%)$, tetapi sintasan ikan bandeng di tambak dengan tipe kandang ayam terapung tidak berbeda nyata $(\mathrm{P}>0,05)$ dengan tipe kandang ayam tancap (Tabel 1). Hal ini disebabkan kandungan amonia 
Tabel 3. Peubah kualitas tanah tambak pada awal dan akhir penelitian.

Table 3. Soil quality parameters of pond at the initial and final stages of experiment.

\begin{tabular}{|c|c|c|c|c|c|c|}
\hline \multirow{2}{*}{$\begin{array}{l}\text { Peubah } \\
\text { Variables }\end{array}$} & \multicolumn{3}{|c|}{ Awal (Initial) } & \multicolumn{3}{|c|}{ Akhir (Final) } \\
\hline & $\mathbf{A}$ & B & $\mathbf{C}$ & $\mathbf{A}$ & B & C \\
\hline $\mathrm{pH}$ & $5.67-6.01$ & $5.94-6.36$ & $5.76-6.84$ & $5.85 \cdot 6.75$ & $6.01-6.42$ & $6.21 \cdot 7.23$ \\
\hline $\begin{array}{l}\text { Jumlah bahan organik } \\
\text { Total Organik Matter (\%) }\end{array}$ & $7.35-13.68$ & $6.87-8.52$ & $7.39-8.01$ & $10.26-22.33$ & $8.53-10.20$ & $8.18-8.38$ \\
\hline Pasir (Sand) & $43.74-59.98$ & $27.95-50.63$ & $51.38-68.09$ & $\cdot$ & - & $\cdot$ \\
\hline Lempung (Clay) & $4.76-14.89$ & $10.58-11.78$ & $5.48-10.60$ & $\cdot$ & - & - \\
\hline Lumpur (Silt) & $35.60-41.37$ & $37.59-61.44$ & $21.31-43.14$ & - & & \\
\hline $\begin{array}{l}\text { Kelas tekstur (Texture } \\
\text { class) }\end{array}$ & $\begin{array}{l}\text { Liat berpasir } \\
\text { (Sandy loam) }\end{array}$ & $\begin{array}{l}\text { Liat berpasir } \\
\text { (Sandy loam) }\end{array}$ & $\begin{array}{l}\text { Liat berpasir } \\
\text { (Sandy loam) }\end{array}$ & & & \\
\hline
\end{tabular}

A Kandang ayam tancap (Pen chicken coop)

B Kandang ayam terapung (Floating chicken coop)

C Kontrol (Control)

dan nitrit yang bersifat racun tidak berpengaruh terhadap sintasan ikan pada kedua perlakuan. Menurut Poernomo (1988) bahwa daya racun amonia peranannya dalam menghambat pertumbuhan dan mematikan ikan sangat dipengaruhi oleh keberadaan $\mathrm{pH}$, suhu, kadar garam dan kadar kalsium dalam perairan tambak. Daya racun amonia meningkat pada suhu dan $\mathrm{pH}$ yang semakin tinggi, kadar garam dan kesadahan rendah.

Kontrol lebih rendah sintasannya dan berbeda nyata $(\mathrm{P}<0,05)$ dari perlakuan yang lain. Hal ini disebabkan tidak adanya introduksi unsur hara yang terdekomposisi dari kotoran ayam secara kontinu. Kandungan hara terutama unsur fosfat dan nitrat (Tabel 5), komposisi spesies dan jumlah plankton (Tabel 2) pada kontrol terendah, walaupun jumlah pupuk (urea dan TSP) yang diaplikasikan sama dengan tipe kandang ayam tancap dan terapung, sehingga pakan alami tidak tersedia dan dapat menurunkan sintasan dan pertumbuhan bandeng.

\section{Produksi}

Produksi bandeng yang dihasilkan oleh perlakuan tipe kandang ayam terapung $(38,95 \mathrm{~kg})$ lebih tinggi dan berbeda nyata $(\mathrm{P}<0,05)$ dengan perlakuan tipe kandang ayam tancap $(26,97 \mathrm{~kg})$, sedang pada kontrol lebih rendah $(11,05 \mathrm{~kg})$ dan berbeda nyata $(P<0,05)$ dengan perlakuan tipe kandang ayam tancap dan terapung (Tabel 1). Hal ini berarti bahwa walaupun sintasan ikan pada kedua perlakuan relatif sama, namun dengan pertumbuhan bobot akhir pada perlakuan tipe kandang ayam terapung lebih tinggi dari pada perlakuan tipe kandang ayam tancap, sehingga menghasilkan produksi ikan yang lebih tinggi pula. Sedangkan pertumbuhan bobot akhir dan sintasan pada kontrol lebih rendah, sehingga menghasilkan produksi ikan yang lebih rendah pula dibandingkan dengan kedua perlakuan. Menurut Shang (1986), sintasan dan pertumbuhan yang tinggi merupakan faktor penting dalam meningkatkan produksi. Kandang ayam terapung yang digerakkan ke seluruh areal tambak dengan interval waktu tiga kali seminggu dan diikuti oleh populasi ikan bandeng di bawahnya akan terjadi gerakan air yang dapat mempercepat proses dekomposisi bahan organik (kotoran ayam) menjadi unsur hara secara merata di tambak yang langsung dimanfaatkan untuk pertumbuhan pakan alami, sehingga dapat meningkatkan produksi bandeng tanpa menurunkan kualitas airnya.

\section{Ayam}

Pertumbuhan bobot, sintasan, dan produksi ayam relatif lebih tinggi pada perlakuan tipe kandang ayam terapung (Tabel 4). Hal ini diduga karena kandang ayam terapung mempunyai 
desain dan konstruksi yang dilengkapi pelampung serta posisinya lebih rendah dan dekat dengan permukaan air yang dihubungkan dengan tali nilon berdiameter tiga $\mathrm{cm}$ dan diikatkan pada beberapa patok kayu yang berada di sepanjang pematang tambak, sehingga dapat melindungi ayam dari hempasan angin yang kencang. Walaupun demikian hasil yang dicapai terutama sintasan ayam oleh kedua perlakuan relatif rendah karena bertepatan dengan musim peng. hujan. Hal ini diduga bahwa ayam buras dengan bobot 550 g/ekor yang berasal dari daerah pedalaman kurang tahan beradaptasi dengan kondisi lingkungan tambak (daerah pantai) dan juga lebih banyak mendapat tekanan suhu udara yang rełatif rendah $\left(24,8^{\circ} \mathrm{C}\right)$ akibat hujan dan angin selama pemeliharaan.

\section{Kualitas air}

Nilai peubah kualitas air harian selama penelitian (Tabel 5) menunjukkan masih berada pada rentang yang layak bagi kehidupan dan pertumbuhan ikan bandeng. Menurut Cholik (1979) kadar $\mathrm{NH}_{3}-\mathrm{N}$ dalam air dianggap aman bagi ikan apabila tidak lebih dari $0,1 \mathrm{ppm}$. Ikan bandeng dapat tumbuh dengan baik pada salinitas 5-40 ppt bahkan dapat mentolerir salinitas 0-60 ppt (Panikkan dalain Gopalakrishna, 1972).

Tabel 4. Pertumbuhan bobot, sintasan, dan produksi ayam selama 75 hari.

Table 4. Weight growth, survival rate, and production of chicken during 75 days.

\begin{tabular}{lrcc}
\hline \multicolumn{1}{c}{$\begin{array}{c}\text { Peubah } \\
\text { Variables }\end{array}$} & & $\begin{array}{c}\text { Kandang ayam tancap } \\
\text { Pen chicken coop }\end{array}$ & $\begin{array}{c}\text { Kandang ayam terapung } \\
\text { Floating chicken coop }\end{array}$ \\
\hline Bobot awal (Initial weight) & $(\mathrm{g})$ & 550 & 550 \\
Bobot akhir (Final weight) & $(\mathrm{g})$ & 960 & 1150 \\
Sintasan (Survival rate) & $(\%)$ & 44.0 & 50.8 \\
Produksi (Production) & (kg/pond) & 10.56 & 14.60 \\
\hline
\end{tabular}

Tabel 5. Kualitas air tambak selama penelitian.

Table 5. Water quality of pond during experiment.

\begin{tabular}{lcccc}
\hline \multicolumn{1}{c}{$\begin{array}{c}\text { Peubah } \\
\text { Variables }\end{array}$} & & \multicolumn{2}{c}{ Tipe kandang ayam (Chicken coop type) } \\
& & $\mathrm{A}$ & $\mathbf{B}$ & $\mathrm{C}$ \\
\hline Kedalaman (Depth) & $(\mathrm{cm})$ & $70-80$ & $70-80$ & $70-80$ \\
Kecerahan (Transparancy) & $(\mathrm{cm})$ & $40-45$ & $35-40$ & $45-50$ \\
Suhu (Temperature) & $\left({ }^{\circ} \mathrm{C}\right)$ & $26.8-31.6$ & $26.7-31.5$ & $26.8-31.5$ \\
Oksigen terlarut (Dissolved Oxygen) & $(\mathrm{ppm})$ & $5.0-8.4$ & $5.2-8.0$ & $5.3-8.2$ \\
pH & & $7.0-8.0$ & $7.0-8.0$ & $7.0-8.0$ \\
Salinitas (Salinity) & $(\mathrm{ppt})$ & $3.0-14.0$ & $5.0-13.0$ & $2.0-14.0$ \\
Total bahan organik (TOM) & $(\mathrm{ppm})$ & $2.53-35.41$ & $3.26-40.82$ & $2.53-26.88$ \\
Total Suspended Solute & $(\mathrm{ppm})$ & $192-1245$ & $125-1170$ & $120-1028$ \\
$\mathrm{NH}_{3}-\mathrm{N}$ & $(\mathrm{ppm})$ & $0.0214-0.0662$ & $0.0193-0.0578$ & $0.0189-0.0445$ \\
$\mathrm{NO}_{2}-\mathrm{N}$ & $(\mathrm{ppm})$ & $0.0044-0.1900$ & $0.0039-0.1960$ & nd-0.0207 \\
$\mathrm{NO}_{3}-\mathrm{N}$ & $(\mathrm{ppm})$ & nd- -0.0054 & nd- 0.0057 & nd -0.0042 \\
$\mathrm{PO}_{4}-\mathrm{P}$ & $(\mathrm{ppm})$ & $0.0113-0.0498$ & $0.0115-0.0353$ & $0.0116-0.0035$ \\
$\mathrm{Fe}$ & $(\mathrm{ppm})$ & nd & nd & nd \\
\hline
\end{tabular}

A Kandang ayam tancap (Pen chicken coop)

B Kandang ayam terapung (Floating chicken coop)

C Kontrol (Control)

nd tidak dapat terdeteksi (not detectable) 
Kualitas air yang baik untuk budidaya ikan bandeng antara lain salinitas $15-30 \mathrm{ppt}$, suhu $27-31^{\circ} \mathrm{C}$, pH $7-8,5$, oksigen terlarut $3-8 \mathrm{ppm}$, alkalinitas $150 \mathrm{ppm}$, kecerahan $20.40 \mathrm{~cm}$, dan bebas pencemaran (Ismail, 1994).

\section{KESIMPULAN}

Pertumbuhan bobot dan produksi ikan bandeng yang terbaik dicapai pada perlakuan tipe kandang ayam terapung, masing-masing sebesar 131,8 g/ekor dan $38,95 \mathrm{~kg}$ dan berbeda nyata $(P<0,05)$ dengan perlakuan yang lain. Sintasan ikan bandeng pada perlakuan tipe kandang ayam tancap dan terapung tidak berbeda nyata $(P>0,05)$, tetapi lebih tinggi daripada kontrol.

\section{DAFTAR PUSTAKA}

Anggoro, S. 1984. Pengaruh salinitas terhadap kualitas dan kuantitas makanan alami serta produksi biomassa nener bandeng. Tesis Pasca Sarjana, Fakultas Pasca Sarjana, Institut Pertanian Bogor. 109 hal.

Bambang S.R. and A.M. Pirzan. 1977. Effect of stocking density on the rate of growth of milkfish fry (Chanos chanos). Bulletin of the Brackishwater Aquaculture Development Centre, Jepara 3(1\&2): 247-257.

Cholik, F, 1979. Budidaya bandeng (Chanos chanos Forsk). Budidaya Perikanan. Badan Pendidikan Latihan dan Penyuluhan Pertanian. Departemen Pertanian Bogor. 30 hal.

Cholik, F dan M.J.R. Yakob. 1987. Budidaya bandeng (Chanos chanos Forsk) secara terpadu dengan ayam pedaging di kolam air tawar. Laporan Penelitian, Balai Penelitian Budidaya Pantai. Un Publish. 11 hal.

Effendie, M. I. 1979. Metode biologi perikanan. Cetakan Pertama. Yayasan Dewi Sri, Bogor. 112 hal. '

Gopalakrishna, V. 1972. Taxonomy and biology of tropical finfish for coastal aquaculture in the Indo-Pasific Region. p.120-49. In Pillay, T.V.R (Ed.) Coastal Aquaculture in the Indo-Pasific Region FAO/IPEC/Fishing News Book, Ltd. London.

Hadijjah. 1985. Penuntun praktikum planktonologi. Fakultas Perikanan. Institut Pertanian Bogor, Bogor. 40 hal.
Huet, M. 1971. Text book of fish culture. Breeding and Cultivation of Fish. Fishing News Book Ltd, London. 436 p.

Ilyas, S., F. Cholik, A. Poernomo, W. Ismail, R.A. Arifuddin, T. Daulay, A. Ismail, S. Koesoemadinata, I.N.S. Rabegnatar, H.H. Suharto, Z.I. Azwar, dan S. Eko Wardoyo. 1987. Petunjuk teknis bagi pengoperasian unit usaha pembesaran udang windu. Seri Pengembangan Hasil Penelitian Perikanan No.PHP/KAN/02/1987. Departemen Pertanian. Badan Penelitian dan Pengembangan Pertanian. Pusat Penelitian dan Pengembangan Perikanan, Jakarta. 100 hal.

Ismail, A., A. Poernomo, P. Sunyoto, Wedjatmiko, Dharmadi, dan R.A.I. Budiman. 1994. Pedoman teknis usaha pembesaran ikan bandeng di Indonesia. Seri Pengembangan Hasil Penelitian Perikanan No./PHP/KAN/26/1994. Departemen Pertanian. Badan Penelitian dan Pengembangan Pertanian. Pusat Penelitian dan Pengembangan Perikanan, Jakarta. 73 hal.

Koesoemadinata, S. 1980. Pesticides as a major constraints to integrated agriculture-aquaculture farming systems. p.45-52. In Pullin, R.S.V. and Z.H. Shehadeh (Eds.). Integrated Agriculture - Aquaculture Farming Systems. ICLARM Conference Proceedings 4, Manila, Los Banos, Laguna, Philippines.

Kusno, S. 1991. Memelihara ikan bersama ayam. Penebar Swadaya. Jakarta. 28 hal.

Lund, R.E. 1985. A user guide to MSUSTAT. Montana State University, Bozeman, MT.

Mintardjo, K., A. Sunaryanto, Utaminingsih, dan Hermiyaningsih. 1984. Persyaratan tanah dan air, hal.63-89. Dalam Pedoman Budidaya Tambak. Direktorat Jenderal Perikanan, Departemen Pertanian.

Newell, G.E. and R.C Newell. 1977. Marine plankton. A Practical Guide. Fifth Edition. Hutchinson \& Co. Ltd., London. 244 p.

Petersen, R.G. 1985. Design and analysis of experiment. Marcel Dekker, Inc., New York-Basel. 429 p.

Poernomo, A. 1988. Pembuatan tambak udang Di Indonesia. Seri Pengembangan No. 7, 1988. Departemen Pertanian, Badan Penelitian dan Pengembangan Pertanian, Balai Penelitian Perikanan Budidaya Pantai, Maros. 30 hal.

Sachlan, M. 1980. Planktonologi. Fakultas Peternakan dan Perikanan, Universitas Diponegoro, Semarang. 130 hal. 
Shang, Y.C. 1986. Analisa ekonomi mikro dari proyek percobaan budidaya perairan; konsep dan definisi. hal 114-24. Dalam Penelitian Ekonomi Budidaya Perairan di Asia. Yayasan Obor Indonesia dan PT Gramedia, Jakarta.

Sin, W.C.A. 1980. Integrated animal fish husbandry system with case studies in duck fish and goose fish. p.113-124. In Pullin, R.S.V. and Z.H. Shehadeh (Eds). Integrated Agriculture - Aquacultúre Farming Systems. ICLARM Conference
Proceedings 4, Manila, Los Banos, Laguna, Philippines.

Soepardi, G. 1983. Sifat dan ciri tanah. Institut Pertanian Bogor (IPB), Bogor. 591 hal.

Stickney, R. 1979. Principle of warm water aquaculture. Wiley Interscience Publication, New York. $475 \mathrm{p}$.

Yamaji, I. 1966. Illustration of the marine plankton of Japan. Hoikusha Publishing Co. Ltd., Japan. 369 p. 